\title{
Friction in mobilities: Migrating to escape
}

\author{
Nguyen Hong Chi ${ }^{1 *}$ \\ ${ }^{1}$ FPT University, Vietnam \\ *Corresponding author: chinh6@fe.edu.vn
}

\begin{tabular}{|c|c|}
\hline ARTICLE INFO & ABSTRACT \\
\hline $\begin{array}{l}\text { DOI: } 10.46223 / \text { HCMCOUJS. } \\
\text { econ.en.9.1.173.2019 }\end{array}$ & $\begin{array}{l}\text { This study investigates professional migration from } \\
\text { Vietnam to Australia and discusses one set of migration } \\
\text { decisions previously published by H. C. Nguyen (2015). By }\end{array}$ \\
\hline Received: September $15^{\text {th }}, 2018$ & \\
\hline Revised: October $14^{\text {th }}, 2018$ & study conceptualizes decision-making processes using \\
\hline Accepted: March $4^{\text {th }}, 2019$ & $\begin{array}{l}\text { Heideggerian terms friction and possibilities. This paper } \\
\text { contributes to findings by previous research in that migration }\end{array}$ \\
\hline Keywords: & $\begin{array}{l}\text { decisions are neither formed by pushes from the sending } \\
\text { country nor pulls from the receiving country. Instead, migrants }\end{array}$ \\
\hline $\begin{array}{l}\text { friction, Heideggerian } \\
\text { phenomenology, migration } \\
\text { decisions, possibilities, skilled } \\
\text { migration }\end{array}$ & $\begin{array}{l}\text { are regarded as active agents striving to manoeuvre their } \\
\text { ontological beings by realizing interrelated possibilities out of } \\
\text { constraints caused by their encounters with political, economic, } \\
\text { social and familial structures that shape their aspirations for } \\
\text { migration. }\end{array}$ \\
\hline
\end{tabular}

\section{Overview of research on the initiation of professional migration from Vietnam}

Most recent research on decisions for professional migration from Vietnam (Dang, 2007; Dang, Tacoli, \& Hoang, 2003; Wickramasekara, 2002) has adopted either neo-classical economic theories. These theories mainly focus on geographic differences in labour division between sending and receiving countries or on economic factors that push professional migrants to leave Vietnam andfull them to other foreign countries. Another strand of research using new economic theories at communal and familial contexts (C. V. Nguyen \& Mont, 2012; P. T. Nguyen, Tran, M. T. Nguyen, \& Oostendorp, 2008) postulates that family and ethnic network factors influence migration decisions of Vietnamese professionals. Attempting to examine Vietnamese professional mobility patterns at a macro level, some research briefly mentions political and social chaos after the Vietnam War as factors of a huge exodus of Vietnamese migrants between 1975 and early 1990s (Gribble, 2011; H. C. Nguyen, 2013). Similarly, some studies and government reports (Dang, Tran, Nguyen, \& Dao, 2010; Ministry of Foreign Affairs, 2012) only explores the work migration growth as a consequence of the Doi Moi Policy without examining the gradual development of other government's policies for Vietnam's global market integration. 
These studies share some common themes with the widest body of recent research on transnational mobilities (Jazayery, 2002; Li, Findlay, Jowett, \& Skeldon, 1996). Extant research on transnational mobilities has acknowledged economic and political conditions as main factors leading to migration. However, how these factors come in friction with other factors at mezzo-and micro-levels is largely unattended, whereas migrants' aspirations and lives are often shaped by the interplay of multiplex phenomena including historical experience, structural conditions, and the ideologies of their home and host societies (Glick-Schiller, Basch, \& Blanc-Szanton, 1999, p. 33). More importantly, the current research profile on Vietnamese professional migrants' decisions to migrate tends to examine political factors separately from the community, household and individual circumstances. These studies view potential migrants as agents being affected by economic and political changes, without examining how these agents' interactions with political, economic, social and familial structures may shape their aspirations for migration.

Migrants have their own lifestyle. They also have families to take care of and nurture aspirations for a better future. They never live separately from the effects of either economic or political transformations alone but within an interrelated network of social and familial structures. Their encounters with these structures may create forces and tension that shape their decisions to migrate. The tension formed through their interactions is normally conceptualized as friction. Friction appears as constraints that seize the migrants' personal and professional development, and possibilities that drive the initiation of migration.

This paper outlines reasons for migration, with a particular focus on friction and the opening of possibilities that initiate Vietnamese two-step migration to Australia. By borrowing the term "friction" in mobilities by Cresswell (2013), the paper theorizes this term in relation to the Heideggerian term of "possibilities" (Heidegger, 1962) through migrants' interactions with the surrounding social milieu. The understandings of friction within mobilities and ways migrants follow to confront it by utilizing possibilities as opportunities and tackling possibilities as challenges that lead to further opportunities can add nuance to the conventional perception that migration is initiated by influences of sole factors such as economic attractions in receiving countries or political turmoil in sending ones. This theoretical perspective also offers new insight into methodological debates between neo-classical economic and (new) economic theories which, as mentioned above, largely ignore the intersecting confluences of factors at diverse scales. To unpack this argument, the paper begins with the theoretical concepts of friction and possibilities before introducing the research site and instrument. The section that follows provides an analysis of the empirical research material that the author collected during his doctoral studies in Australia. The paper concludes that the initiation of skilled migration can be caused by migrants' embeddedness in the world that creates both tensions and chances for them to make sense of their beings and becoming through migration.

\section{Friction as constraints with possibilities}

In common sense, friction is a force which resists or slows down the motion of two or more materials sliding and rubbing against each other (Cresswell, 2013, p. 1). It can happen between moving materials, as well as between moving and stationary materials. In reality, 
friction tends not to happen between one object and another, but possibly one object or many against several others. It occurs in various directions and scales, leading to different effects on mobility. While the transnational movement of the highly skilled has been mistakenly seen as "evidence of the state losing control" (Cresswell, 2013, p. 20) the role of the nation-state in controlling and managing mobilities has not been weakening. Instead, Favell, Feldblum, and Smith (2007) affirm that highly skilled mobilities are not frictionless, but rather they entail costs and constraints. As H. C. Nguyen (2014) argues, Vietnamese mobilities of both labour and self-initiated migrants are controlled by the Vietnamese government as a strategy either to enhance bilateral relations with other countries or to improve the quality of the workforce. The regime of migration policies in host countries, on the one hand, has facilitated movements of skilled migrants, but on the other, has caused certain friction for those from developing sending countries. Institutional and political regimes may shape migrants' motives and desires, making them "particular kinds of subjects in the world" (Ong, 1999, p. 6). In addition, influences from communities and families, which play an important role in shaping migrants' intention to migrate, also cause friction in forming migration decisions. Migrants are not solely the objects of state policies that manoeuvre under the direction of the political regimes or being affected by communal and familial contexts. As active agents, they respond to such contexts by using the opening of possibilities as opportunities and challenges.

According to Heidegger (1962, p. 183), possibilities neither mean "not yet actual" possibilities nor simply logical possibilities. Instead, we find ourselves as already having possibilities as a potentiality of acting and being, such as the potentiality of knowing how to use bribery as a strategy that one migrant in this study practiced dealing with her projection into becoming a two-step migrant. Possibilities are not "abstract thoughts" (Hoy, 1993, p. 178), but are recognized through our specific activities. On the one hand, we are constrained by "routines and ready-made solutions" and by our own history and traditions (Dall'Alba, 2009, p. 40). On the other, we also face tension through interactions with others in indirect macrocontexts and direct personal circumstances. Possibilities, in this sense, are not "free-floating" (Heidegger, 1962, p. 183) or "spontaneously free" choices (Hoy, 1993, p. 179), as we do not always rationally realize or make choices. Instead, we project into the future by understanding what matters to us by emerging into a context of meanings we assign for things. How we assign meanings to things depends on how we attempt to make sense of our activities. In this vein, our relations to the world are ambiguous (Dall'Alba, 2009, p. 37).

Our relations to the world are ambiguous because our lifestyle and living experiences are not always the same and things appear different in different situations. The ambiguity leads to the opening of possibilities about the ways we may choose to live in accordance with the position we embrace for our ways of being (Dall'Alba, 2009, p. 38). During our lives, we interact with others and things as equipment in totality. In this vein, the ways things become manifest themselves cannot be isolated. As such, one factor may not lead to the sole reason for migration, but a concert of factors influences migrants' decisions to migrate. Migrants can choose possibilities that fit expectations of their present ways of being and future orientation. Yet, possibilities are not endless because constraints and resistance always occur along the way 
they live their lives. Constraints do not always block their projection into the future, but rather they can impede or lead to other possibilities. In this sense, migrants experience the opening of constraints with possibilities as friction.

Friction is not only produced through the rubbing of individuals against the regime of political power or against one social factor separately but also through migrants' interactions with social structures. Migrants' dealings with the world allow them to achieve their aspirations in relation to others and their historicity. The perspective on friction in this study argues against the cosmopolitan viewpoint that views highly skilled mobilities as free-floating under globalization forces. Friction is a force that can slow down as constraints or speed up migration as possibilities when migrants attempt to live with others in the surrounding world. The data analysis in this paper illustrates how the research participants experienced friction that constrained them from migrating and/or enabled them to migrate.

\section{Research sites and instrument}

15 professional migrants aged between 29 and 42 from Vietnam residing in the cities of Brisbane in the Australian state of Queensland, Sydney in New South Wales, and Melbourne in Victoria were chosen for the study through the snowball sampling technique. This research cohort included 7 female and 8 male migrants, among whom one was divorced, four were single, and the rest were married with and without children. They had obtained either Bachelor's, Master's and/or doctoral degrees in different fields conferred onshore by different Australian universities. All were working in various white-collar employment sectors, and almost decided not to return to Vietnam after they had completed their studies in Australia. While 13 participants had their PR granted onshore since 2001, the other 2 applied for PR from Vietnam.

In this study, the author primarily used Heidegger's phenomenology to interpret the meanings of the informants' living experience. Employed in a range of disciplines such as health, economics, psychology and education, the number of 5 to 10 participants is recommended (e.g., Cope, 2011, pp. 608-609; Dukes, 1984, p. 200; J. A. Smith, 2004, p. 42) for this phenomenological approach so that researchers can "see the logic or meaning of an experience [...] rather than to discover causal connections or patterns of correlation" (Dukes, 1984, p. 197). Moreover, the small sample size also helped researchers reflect on the complexities of the participants' lives and examine the connections and contradictions between different aspects of their accounts. The author went beyond the suggested number of participants to ensure that the experiences of a broad range of students-turned-migrants could be properly explored.

Based on Heideggerian phenomenology, the researcher conducted interpretative conversations with the participants. These conversations were guided by two sets of questions. The first set enabled the researcher to obtain an initial understanding of the participants' background and context. The second set of questions explored issues related to the research questions on the negotiation of transnational mobilities. In this part of the conversation, the researcher aimed to examine the links between social transformations and transnational mobilities that involved the complexity, contextuality and interconnectedness of multi-level 
meditations of migration processes in Vietnam and Australia (Castles, 2010, p. 1565). The researcher also explored how the participants encountered and interacted with these influences from the socio-political structures, effects on their professional and familial lives, as well as how these shaped their decisions to migrate.

\section{Friction that causes migration as an escape}

This section analyses the research material in relation to one set of the participants' migration decisions. The study found that there were at least 4 interrelated types of migration decisions as an escape. These 4 types are then conceptualized within the concepts of friction and possibilities.

\subsection{Lack of political patronage}

It should be noted here that the participants in this study not only encountered one set of migration factors but also a concert of influences at the same time. For instance, they experienced a lack of political power in dealing with both family and work problems. Eight of the participants (Thanh Huong, Yen Xuan, Quynh Hoa, Xuan Hong, Ngoc Dai, Van Minh, Thanh Binh \& Minh Thanh) experienced a lack of political alliance at their former workplaces as one of the drives for migration. Having perceived a lack of political patronage in their former educational work, Thanh Huong and Xuan Hong metaphorically defined political alliance as an "umbrella" and "root". For example, Thanh Huong referred to her lack of political power and connections with those in power as an English teacher at a secondary school to unfair treatment at work as follows:

"Other teachers just copied the lesson plans from the internet or somewhere else, and they were considered as the standard. I designed the lesson plans by myself and ended up with being criticized for not following the standard".

Such experience in politics shows that her relation with others seems to be acknowledged by the need for having an "umbrella" and linked to other workplace issues that will be discussed later in this section. Her perceived lack of political patronage as one of the reasons for migration reflects the findings of previous studies (Jazayery, 2002; Li et al.,1996; Rogers, 1992) with a focus on "migration potential" rather than "migration pressures" caused by political ruptures in sending countries (Rogers, 1992, p. 36). While these studies point out the lack of political power as one of the motives for migration, they fail to mention the actual experiences of migrants where they find themselves as insufficient and incapable of interactions with others in the world. That small world of hers just included broader political regimes and relationships with colleagues.

Like Thanh Huong and Quynh Hoa witnessed that her colleagues had to live under pressure from the disconnection with the political alliance. She had the same experience with Ngoc Dai, an information technology engineer with a doctoral degree conferred by an Australian university, who referred political affiliation to a "big umbrella". In Vietnamese society, the concept "umbrella" connotatively means the hidden power of political and social connections which shelter one's interest and security, and "root" shows one's family relationship with those in power. Thanh Huong believed that by tying each other's interests in 
the same community was not correctly embodied as a type of cooperation for work, but rather a sign of power use for defending one's benefit and "pulling somebody down because that person [did] not have any power" [her words]. Such social concepts as "umbrella", "root", and "raft" are normally used in Vietnam with a mocking sense of those connected to power and the widespread aspiration to establish a network with the powerful for individual goods. In these migrants' cases, facing the lack of social relationships can be conceptualized as a constraint that led to their migration.

This result shows some slight differences from previous research on political factors as a driver for migration. For example, political secessions such as violent conflicts between the government and civilians in terms of economic benefits, human rights and war-related issues were commonly associated with a "push" factor among the flows of professionals in the 1960s and 1970s in Europe (Glaser, 1978; Kindleberger, 1968; Rao, 1979) or as political and social chaos after the Vietnam War (Gribble, 2011; H. C. Nguyen, 2013). Similarly, driven by continuous internal political chaos, a large number of Afghan professionals have migrated to western countries as either refugees or skilled migrants (Hanifi, 2006; Jazayery, 2002). Lorenzo, Galvez-Tan, Icamina, and Javier (2007) revealed that social and political instability was one of the push factors driving Filipino nurses to migrate to the Middle East and North America. In general, these studies collectively consider political instability in home countries as a force that "pushes" professionals to migrate. Despite some similarities, the present study regards political force as a constraint to migrants' personal and professional development. In facing the lack of political power, they could find a possibility of either establishing social relationships with others as an inauthentic mode of being or deciding to remain in Australia after graduation. Besides, there are other constraints will be discussed below.

\subsection{Limited recognition and career prospects as professionals}

Tansel and Gungor (2003)'s survey finds that the lack of job opportunities due to political and economic instability in Turkey impedes the return of both prospective returning students and returnees who struggle to adapt to the working environment there. Likewise, through an in-depth qualitative study of six focus groups and a number of interviews with international students in the US, Hazen and Alberts (2006) identify a lack of employment opportunities in home countries as one of the most notable factors preventing international students from returning home after graduation. In contrast, a number of migrants including twostep migrants from Hong Kong to Canada are found to return to Hong Kong for employment and business opportunities after the island emerged as a hub of commerce and a cosmopolitan lifestyle (Ley \& Kobayashi, 2005). Similarly, Balaz and Williams (2004) confirm that Slovakian students returning from the UK enjoy not only an increase in their individual welfare and incomes but also a higher social recognition thanks to their English language proficiency, attitudinal and interpersonal competences. Gaining social status and recognition is also identified as one of the main factors that pull students to return home for employment (Hunger, 2002; H. C. Nguyen, 2005). It can be implied from different findings of these studies that the prospects of international students and two-step migrants' public recognition gained upon their return are still debatable. This section aims to add further insights into this debate by examining 
potential migrants' aspirations for migration in everyday interactions with other people in their environment through the phenomenological perspective.

After returning home from their first education journey to Australia, Yen Xuan, Thanh Binh, Thai Duong and Thanh Huong began to feel bored with their jobs in Vietnam. This arose from the working mechanism which did not recognize creativity on work performance. Thanh Huong encountered a "ridiculous" [her word] working environment where those without a close connection with powerful people were severely supervised. Her lesson plans were checked more frequently than other peers with "big roots", and she told the researcher that she was observed too regularly because "he [the headmaster] thought that [she] was always a novice practitioner." The result of this unreasonable conduct of management and leadership had made her feel distressed about her work.

A lack of political power also led to a lack of public recognition of qualifications for Thanh Huong and Yen Xuan. In this vein, the constraint of public recognition was experienced in close relation to the constraint of political power. This result challenges extant studies examining separate factors that impede international students and migrants from their way back home. These studies can help explain how returning migrants experience various factors affecting their career development but they just categorize such influences into separate entities without acknowledging that entities may well "spill over into one another" (Dall'Alba, 2009, p. 38). The lack of unanimous recognition and limited career prospects entailed different meanings to these migrants through their dealings with these aspects. Such aspects did not present themselves as objective entities but as situations with "serviceability" (Heidegger, 1962, p. 184) appeared as a condition for these migrants to respond to their involvement with the world. This involvement related to a system of references including the constraints and the migrants' aspirations to migrate. Other constraints included their suspicion of bribery and corruption practices in Vietnam.

\subsection{Suspicion of bribery and corruption}

Vietnam's corruption index was ranked 116 out of 175 countries in 2013 and 107 out of 180 countries in 2017 (Transparency International, 2013, 2018). Despite recent achievements in economic stability and growth under the pressure of the world's economic crises in 1997 and 2009, Vietnam Communist Party (VCP) has been unable to tackle the major political issue of corruption (Fforde, 2013, p. 103), which has happened since the VCP adopted privatization on the one hand but increased the sole "leading role" of the VCP on the other (Avery, 1993, p. 69). Fight against corruption has been announced and tackled from every corner of governance. Article 3 of Anti-Corruption Law issued by Vietnam's National Assembly in 2005 clearly specifies 12 "behaviours of corruption" and severe punishment "in front of law" (The Central Government, 2005). However, doubts about the effectiveness of this fight has arisen among public media, mostly from neutral observers (Le, 2012; Ha Mi, 2013) and some anti-communist Vietnamese expatriates (Thanh Quang, 2013; Vu, 2013). Those with aspirations for social advancement may choose to get involved in corruption and bribery practices as a way to obtain their goals. The reality of bribery and corruption is partly reflected through these migrants' experiences as shown below. 
Attempting to escape from the lack of political power, Thanh Huong realized the serviceability of bribery and connections to apply for her passport in 2001 in the following way:

"When I submitted my passport application, my husband suggested me send it through a person, kind of broker, who would take care of everything for me. I paid him 100 USD and received my passport within 30 hours!"

The researcher acknowledges that this study does not claim to discuss any political viewpoint, as it stands neutral in the public debate over this matter. It just shows that reasons for migration can be shaped by migrants' ambiguous relations to the social milieu. For example, Thanh Huong's relation to the bribery practice was ambiguous because it could manifest itself in two different meanings in her situations. Although the lack of trust and recognition at work discouraged her work commitment, she just tries to go with the flow by managing to utilize her existing connections with those in power and bribery. The exploitation of social relationships and bribery was seen as a means to help her achieve her migration goal. In practicing these strategies, she found bribery as a "grease" (Kaufman \& Wei, 1999, p. 1) to smoothen and fasten the administrative process. This behaviour showed that migrants are influenced by the macrocontextual factors of politics through how they interact with others in the social milieu. However, they are able to respond to these factors actively by negotiating available channels of micro-power through social relationships with influential people as a piece of equipment. In this vein, both agency and structures do not exist as two separate entities but, as noted by O'Reilly (2012, p. 17), they are always interdependent and interrelated to the micro-power of individuals. Accordingly, instead of seeing bribery as a constraint, prospective migrants try to translate it into a means to smoothen their journey.

Other participants ironically used terms like "the back door" (by Ngoc Dai) or "an envelope under the table" (by Minh Thanh) to reflect their view on bribery and corruption. For example, according to Quynh Hoa, unjust treatment can be minimized and personal growth opportunities can be enhanced for the powerless through the use of bribery because a lack of political power was perceived to block their way to social and professional advancement. This is similar to Robertson's (2007) findings of two-step migrants in Australia with reference to their migration decisions. In her research, some participants decided to migrate to Australia from their home developing countries to escape the constraints of social ideologies and obligations, social issues and political problems associated with corruption. However, Robertson (2007) does not look into how corruption can be utilized as a possibility to deal with those constraints. This study, on the contrary, shows that migrants' experience in dealing with bribery can be theorized as a possible tool for them to decide to migrate after they had finished their studies in Australia. In this sense, the friction of bribery became both an impeding and enabling factor for migration potentials.

\subsection{Personal upheavals}

Glaser (1978), Gribble (2011), and H. C. Nguyen (2005) have repeatedly confirmed that family connections are seen as one of the most compelling forces driving international 
students to return home. However, these studies do not explicate how family connections affect migrants' decisions to re- migrate, particularly returning international students. This research, however, shows that returning students' decisions to re-migrate are affected by family conditions because migrants are always immersed in the surrounding world with others. In particular, some participants of this study decided to return to Vietnam after their international education journeys due to their strong ties with families and relatives in Vietnam. For example, before permanent migration, Thanh Huong had never thought that she would have landed her life in a foreign country as a migrant because she was enjoying happiness from her family. Nevertheless, her family break-up after her return marked a sad milestone in her life. Her aspirations for a brighter work future were darkened by the failure of family reunion which was filled with "spiciness and bitterness" [her words]. She emphasized that if she had been able to sustain happiness with her family, she would have accepted lower incomes. However, considering the limited political connections that could impede her daughter's education and employment prospects and the emotional trauma from her divorce in Vietnam, she actualized her mobility back to Australia to pursue another Master's degree through a partial scholarship at an Australian university. In this case, Thanh Huong's personal upheavals with her family disorganizations were closely linked to a broader social milieu which included the working environment not valuing her Australian qualifications, her family members and her aspirations of becoming a professional.

Similarly, Xuan Hong's return from her first international education in Australia was disappointing when her marriage ended in a divorce, which made her rush into a decision to migrate to Australia as a remedy for her sadness. Also perceiving migration as an escape, Quynh Hoa stated that there were three main reasons for her to apply for PR in Australia, which were in close relation to the intersecting influences of macro-, mezzo- and micro-contextual factors. These included the lack of political power as mentioned previously, her father's expectations of sending his children to live overseas for a better life and the death of her lover. The loss of her beloved was perceived as the strongest motive for her to migrate to Australia as an escape from her sorrow. This result shows that migration includes an interlinked system of individual circumstances, household influences and social networks. Not only is professional migration mediated by social, political and cultural aspects, but it also mediated by familial influences on personal situations. The historicity and embodiment of these migrants' moorings show that an understanding of "push" factors in current brain drain studies, on the one hand, offers us insights into significant factors ranging from communal to familial factors but on the other, it fails to acknowledge the relationship between these factors when migrants get involved in their "dealing with entities within-the-world" (Heidegger, 1962, p. 95). Studies on migration potentials, therefore, should not only engage with migrants or influences of factors themselves, but also with migrants and their interpretation of their relations to the influences of relevant factors.

\section{Concluding remarks: Friction in migration as an escape}

Migrants never live apart from social networks within and through places with restrictions posed from both macro - structures and micro-constraints. Accordingly, a 
theoretical and methodological approach to understanding patterns and motivations of migration should focus on both agency and structure, considering these two aspects as codetermining. How migrants negotiate their aspirations for migration is mostly influenced by their lifestyle in close connections with socio-economic, political structures and cultural practices, as well as familial contexts. Contact with these structures causes friction. At the macro-level, friction is present in the form of state sovereignty in controlling and managing migration. At the micro-level, people still move for various reasons, mostly for a better life and they experience friction with their family and community. The findings of this study suggest that friction can refer to both constraints in migration potentials and possibilities in achieving aspirations for migration. Professional migrants make decisions to migrate based on interactions with the social milieu where they can face challenging constraints. In attempting to achieve their aspirations for a better life, they may find the possibility of migration as an escape from these constraints. Highly skilled migrants' motivations for migration are not only shaped by political or economic rationalities, but also by sociocultural contexts operative at family-community- country scales.

\section{References}

Avery, D. R. (1993). Vietnam in 1992: Win some; lose some. Asian Survey, 33(1), 67-74. doi: $10.2307 / 2645288$

Balaz, V., \& Williams, A. M. (2004). "Been there, done that": International student migration and human capital transfers from the UK to Slovakia. Population, Space and Place, 10(3), 217-237. doi:10.1002/psp.316

Castles, S. (2010). Understanding global migration: A social transformation perspective. Journal of Ethnic and Migration Studies, 36(10), 1565-1586. doi:10.1080/1369183X.2010.489381

Cope, J. (2011). Entrepreneurial learning from failure: An interpretative phenomenological analysis. Journal of Business Venturing, 26(6), 604-623. doi:10.1016/j.jbusvent.2010.06.002

Cresswell, T. (2013). Friction. Paper presented at Theorizing mobilities in/from Asia Conference, Asia Research Institute, National University of Singapore.

Dall'Alba, G. (2009). Learning professional ways of being: Ambiguities of becoming. Educational Philosophy and Theory, 41(1), 34-45. doi:10.1111/j.1469-5812.2008.00475.x

Dang, A. N. (2007). Labour export from Vietnam: Issues of policy and practice. Paper presented at the 8th International Conference of Asia Pacific Migration Research Network (APMRN), Fuzhou, China. 
Dang, A. N., Tacoli, C., \& Hoang, T. X. (2003). Migration in Vietnam: A review of information on current trends and patterns, and their policy implications. Paper presented at the Regional Conference on Migration, Development and Pro-Poor Policy Choices in Asia, Dhaka, Bangladesh.

Dang, A. N., Tran, T. B., Nguyen, N. Q., \& Dao, T. S. (2010). Development on the moveMeasuring and optimizing migration's economic and social impacts in Vietnam (Country Report, Global Development Network). Retrieved March 20, 2018, from https://eccovietnam.wordpress.com/2010/04/03/development-on-the-move-measuringand-optimizing-migration \%e2\%80\%99s-economic-and-social-impacts/

Dukes, S. (1984). Phenomenological methodology in the human sciences. Journal of Religion and Health, 23 (3), 197-203. doi:10.1007/BF00990785

Favell, A., Feldblum, M., \& Smith, M. P. (2007). The human face of global mobility: A research agenda. Society, 44 (2), 15-25. doi:10.1007/BF02819922

Fforde, A. (2013). Vietnam in 2012: The end of the party. Asian Survey, 53(1), 101-108. doi:10.1525/as.2013.53.1.101

Glaser, W. A. (1978). The brain drain: Emigration and return. Oxford, UK: Pergamon Press.

Glick-Schiller, N., Basch, L., \& Blanc-Szanton, C. (1999). Transnationalism: A new analytical framework for understanding migration. In S. Vertovec, \& R. Cohen, (Eds.), Migration, diaspora and transnationalism (pp. 26-49). Northampton, MA: Edward Elgar. doi:10.1111/j.1749-6632.1992.tb33484.x

Gribble, C. (2011). National policies on skilled labour and the cross-border student market, with a focus on Vietnam. In S. Marginson, S. Kaur, \& E. Sawir (Eds.), Higher education in the Asia-Pacific: Strategic responses to globalization (pp. 291-307). Dordrecht, Netherlands: Springer. doi:10.1007/978-94-007-1500-4_15

Hanifi, S. M. (2006). Material and social remittances to Afghanistan. In C. G. Wescott, \& J. M. Brinkerhoff, (Eds.), Converting migration drains into gains: Harnessing the resources of overseas professionals (pp. 98-126). Manila, Philippines: Asian Development Bank.

Hazen, H. D., \& Alberts, H. C. (2006). Visitors or immigrants? International students in the United States. Population, Space and Place, 12(3), 201-216. doi:10.1002/psp.409

Heidegger, M. (1962). Being and time (J. Macquarrie, \& E. Robinson, Trans.). London, UK: SCM Press.

Hoy, D. C. (1993). Heidegger and the hermeneutic turn. In C. B. Guignon (Ed.), The Cambridge companion to Heidegger (pp. 170-194). New York, NY: Cambridge University Press.

Hunger, U. (2002). The brain gain hypothesis: Third world elites in industrialized countries and socioeconomic development in their home country. San Diego, CA: The Centre for Comparative Immigration Studies, The University of California.

Jazayery, L. (2002). The migration-development nexus: Afghanistan case study. International Migration, 40(5), 231-254. doi:10.1111/1468-2435.00218 
Kaufman, D., \& Wei, S.-J. (1999). Does "grease money" speed up the wheels of commerce? NBER Working Paper No. 7093. Cambridge, MA: National Bureau of Economic Research.

Kindleberger, C. P. (1968). Study abroad and emigration. In W. Adams (Ed.), The brain drain (pp.135-155). New York, NY: Macmillan.

Le, H. H. (2012, November 6). Vietnam's fight against corruption: A self-defeating effort? East Asia Forum. Retrieved April 20, 2018, from East Asia Forum website: https://www.eastasiaforum.org/ 2012/11/06/vietnams-fight-against-corruption-a-selfdefeating-effort/

Ley, D., \& Kobayashi, A. (2005). Back to Hong Kong: Return migration or transnational sojourn? Global Networks, 5(2), 111-127. doi:10.1111/j.1471-0374.2005.00110.x

Li, F. L. N., Findlay, A. M., Jowett, A. J., \& Skeldon, R. (1996). Migrating to learn and learning to migrate: A study of the experiences and intentions of international student migrants. International Journal of Population Geography, 2(1), 51-67. doi:10.1002/(SICI)10991220(199603)2:1<51::AID-IJPG17>3.0.CO;2-B

Lorenzo, F. M. E., Galvez-Tan, J., Icamina, K., \& Javier, L. (2007). Nurse migration from a source country perspective: Philippine country case study. Health Services Research, 42(3), 1406-1418. doi:10.1111/j.1475-6773.2007.00716.x

Ha Mi (2013). Why do Vietnam's patients bribe their doctors? Retrieved February 20, 2018, from BBC News Asia website: https://www.bbc.co.uk/news/world-asia-23237285

Ministry of Foreign Affairs. (2012). A review of Vietnamese migration abroad. Retrieved March 20, 2018, from http://eeas.europa.eu/archives/delegations/vietnam/documents/eu_vietnam/vn_migration _abroad_en.pdf

Nguyen, C. V., \& Mont, D. (2012). Economic impacts of international migration and remittances on household welfare in Vietnam. International Journal of Development Issues, 11(2), 144-163. doi:10.1108/14468951211241137

Nguyen, H. C. (2005). To stay or to return? Brain drain or brain gain? (Unpublished master's thesis). The University of Queensland, Brisbane, Australia.

Nguyen, H. C. (2013). Vietnamese international student mobility: Past and current trends. Asian Education and Development Studies, 2(2), 127-148. doi:10.1108/20463161311321411

Nguyen, H. C. (2014). Development and brain drain. Migration and Development Journal, 3(2), 181-202. doi:10.1080/21632324.2014.883243

Nguyen, H. C. (2015). Transnational mobilities of Australia-educated and domiciled professional migrants from Vietnam (Unpublished doctoral dissertation). University of Queensland, Brisbane, Australia. doi:10.14264/uql.2015.1020 
Nguyen, P. T., Tran, T. N. T. M., Nguyen, N. T., \& Oostendorp, R. (2008). Determinants and impacts of migration in Vietnam (Depocen Working Paper Series No. 2008/01). Retrieved March 25, 2018, from http://www.depocenwp.org/upload/pubs/TranNgoMinhTam/Determinants\%20and\%20I mpacts\%20of\%20Migration\%20in\%20Vietnam_DEPOCENWP.pdf

O’Reilly, K. (2012). International migration and social theory. New York, NY: Palgrave Macmillan.

Ong, A. (1999). Flexible citizenship: The cultural logics of globalization. London, UK: Duke University Press.

Rao, G. L. (1979). Brain drain and foreign students. Brisbane, Queensland: The University of Queensland Press.

Robertson, S. K. (2007). Escape, engagement and ethics. The human face of brain drain from the student-turned-migrant perspective. Paper presented at Education without Borders 2011, UAE. Retrieved March 25, 2018, from http://ewb.hct.ac.ae/2007/studentpapers/brain-drain-student-turned-migrant-perspective/

Rogers, R. (1992). The politics of migration in the contemporary world. International Migration, 30(s1), 33-55. doi:10.1111/j.1468-2435.1992.tb00774.x

Smith, J. A. (2004). Reflecting on the development interpretative phenomenological analysis and its contribution to qualitative research in psychology. Qualitative Research in Psychology, 1(1), 39-54.

Smith, M. P. (2005). Transnational urbanism revisited. Journal of Ethnic and Migration Studies, 31(2), 235-244. doi:10.1080/1369183042000339909

Tansel, A., \& Gungor, N. D. (2003). "Brain drain" from Turkey: Survey evidence of student non-return. Career Development International, 8(2), 52-69. doi:10.2139/ssrn.441160

Thanh Quang (2013). Chống tham nhũng ở Việt Nam là tụ sát? [Fight against corruption means suicide]. Retrieved April 25, 2018, from http://www.rfa.org/vietnamese/indepth/vnfight-corrupt-is-kill-himself-01142013124432.html

The Central Government. (2005). The anti-corruption law. Hanoi, Vietnam: The Central Government. $\quad$ Retrieved April 27, 2018, from http://www.chinhphu.vn/portal/page/portal/chinhphu/hethongvanban? class _id=1\&mode=detail\&document_id=29335

Transparency International. (2013). Corruption perceptions index 2013. Retrieved January 25, 2018, from http://cpi.transparency.org/cpi2013/results/

Transparency International. (2018). Corruption perceptions index 2017. Retrieved April 25, 2018, from https://www.transparency.org/country/VNM

Tsing, A. (2005). Friction: An ethnography of global connection. Princeton, NJ: Princeton University Press. 
$\mathrm{Vu}, \mathrm{A}$. (2013). Why is corruption in police always ranked the top? Retrieved April 22, 2018, from http://www.rfa.org/vietnamese/in_depth/y-poli-top-corruption07212013055531.html

Wickramasekara, P. (2002). Asian labour migration: Issues and challenges in an era of globalization (International Migration Papers, No 57). Retrieved April 27, 2018, from https://www.ilo.org/asia/publications/WCMS_160632/lang--en/index.htm 